\title{
Tattua
}

JOURNAL OF PHILOSOPHY

\section{WHITEHEAD AND RELIGION: A STUDY OF THE PHRASE 'THIS UNIVERSE IS THE BODY OF GOD' IN TENRIKYO SCRIPTURES:}

\author{
Midori Horiuchi
}

\begin{abstract}
:
In this presentation, I would like to consider the world as the place of realizing God's salvation for human beings based upon the teachings of Miki Nakayama. The world, the human body and the mind appear to be the three key terms in drawing out a general view of the teachings.
\end{abstract}

Tenrikyo is a religion that is based on the teachings of Miki Nakayama (17981887). According to Tenrikyo doctrine, Miki who is called Oyasama by her followers, received a divine revelation from God the Parent [Oyagami], Tenri-O-no-Mikoto, and was settled as the Shrine of God in 1838. Miki thereafter expounded the wishes of God the Parent for over fifty years. The basic is that humankind was created with the purpose of living a life of joy. The Joyous Life, Miki taught, is the objective of humankind's existence. It is to be collectively shared by people of all nations, who are considered as children of God the Parent. All human beings, therefore, are related to one another as brothers and sisters and, in addition, if ioy is experienced by them, God, too, will share in that joy. 
Not only did Miki instruct her disciples by example, but she also did so through the written word. Two of the three Tenrikyo Scriptures were written by Miki Nakayama herself. They are the Ofudesaki, [The Tip of the Writing Brush], and the Mikagurauta, [The Songs for the Service]. Whereas the former is written in a poetic style containing 1,711 verses, the latter comprises words that are sung for the Kagura and Teodori Services. The Kagura Service consists of a ritual dance with masks which is accompanied by musical instruments and is performed only around the Kanrodai (Central pillar at the sacred place of Thenrikyo, called Jiba where humankind was first conceived). There are ten performers for the Kagura Service, five men and five women, who wear their respective masks and symbolically convey through hand gestures God the Parent's complete providence, which is based on the Moto-no-ri [Story of Origin]. The Teodori, on the other hand, is a ritual dance that is performed by members of the Tenrikyo community for communal religious practice.

The world, the human body, and the mind appear to be three key terms in drawing out a general view of the teachings. The world and the human body are constantly permeated with the blessings of God. It is the mind that alters from one day to the next. These ideas are revealed in the following words from the Ofudesaki. "The universe is the body of God. Ponder this in all matters." (Ofudesaki III: 40\&135, this indicates that this verse is appeared in the Ofudesaki, the $40^{\text {th }}$ and $135^{\text {th }}$ verses of the chapter 3), "All human bodies are things lent by God. Do you know the free and unlimited workings of God?" (III:126) and "So long as you remain unknowing that the body is a thing borrowed, you can understand nothing at all, "(III:137) are instructive verses which while discussing the three key terms, explain why all human beings live in this worldly sphere and are endowed with human bodies.

Professor Arakawa in commenting about "the world is the body of God" in Process Theology, said as follows:

The concept of "The World is the body of God" in Process Theology is understood as follows: That is, God receives all things and events happening in this world including human experiences, and absorbs them into God's own body. Therefore, the richer experiences of human beings and the limited existences in this world are, the richer God's physically life that receives them is. Then, God gives God's own self to the enduring objects of time and persuades them to become a higher perfection. In this sense, God's workings are based on the sympathetic and responsive character. The fact that God's existence is one based on time is because time has been incorporated into God's own body.'

Yoshihiro Arakawa. 'On 'The World is the body of God,' in the Tenri kyogaku kinkyu, no. 42. Tenri: Tenrikyo-doyusha, 2006, $42-43$ 
This is the cosmology from the view of God, and this study is helpful to consider same phrases concerning God's body which are explained as one of the main teachings of salvation in Tenrikyo. For Tenrikyo followers, it is important that human beings are born and live in this world and through their experiences, their human relations and their surroundings they can mature in this world. In the Doctrine of Tenrikyo it is stated:

This universe is the body of God the Parent and is filled with divine providence. Manifested as fire, water, and wind, divine providence can be seen, but at the same time it governs the entire universe with majestic authority, invisibly, as the truth of heaven. It is the source of life for all that is - the origin of all phenomena. ${ }^{2}$

Therefore, it is said that the unlimited workings of divine providence can be distinctly seen by our eyes, felt by our bodies, and sensed by our minds, ${ }^{3}$ because God the Parent not only created human beings and the world but has watched over our growth with perpetual parental love, providing us with training in the seasonable times appropriate to our growth. ${ }^{4}$ In other words, the world and the human body are intrinsically analogous to one another in light of the providence of God. That is, the world and the human body are both permeated with the blessings of God the Parent: both are products of a single theme. Furthermore, humanity was created by God simply from the desire that humans would be spirited and, by seeing this spiritedness rise among humanity, God too, could share in it. The key to living a spirited life, however, lies in how humanity handles the mind. ${ }^{5}$ This interrelation between the human body and the world is made through the fact that both are invested with power from an outer source, more precisely, what we call the complete providence of the God. It is evident that such power does not derive from a human source, but rather, is generated from a higher determinant whom we invoke as God. ${ }^{6}$ Both the world and the human body are material things which receive the boundless grace of God from the very beginning of time and continue to exist because of it: all is the body of God. In this sense, then, the human body is comparable to the world as the world as comparable to the human body. Miki

2 Tenrikyo Church Headquarters (=TCH). The Doctrine of Tenrikyo. Tenrikyo-doyusha, 1993, 32.

3 Translation Section, Tenrikyo Overseas Mission Department (=TS). Tenrikyo The Path to Joyousness. Tenri: Tenrikyo Overseas Mission Department, 1998, 29.

$4 \mathrm{TCH}, 24$.

5 TS. 29.

6 TS, 34. 
Nakayama, the Foundress, once purportedly said: "If you understand (the truth of God's providence in) the human body, you will recognize everything (of the divine providence) in the world."

This is described in the "Story of the Beginning of Origin" and rendered in its present textual form in "The Truth of Origin." 8 For instance, it explains the ten aspects of the complete providence of God the Parent as follows: "Kunitokotachino-Mikoto: in the human body, the divine providence of the eyes and fluids; in the world, the providence of water"; "Omotari-no-Mikoto: in the human body, the divine providence of warmth; in the world, the providence of fire"; and so on. This points out the orderly correlation between the so-called macrocosm and its reflection, which is microcosm.

Hideo Nakajima, Professor Emeritus at Tenri University, wrote concerning the phrase "This universe is the body of God" in relation to the revelation of God in a paper titled"This Universe is the Body of God; Ponder This in all Matters." Here, my discussion is based on his paper. ${ }^{9}$ Professor Nakajima pointed out the several forms of God's revelations. The first one is the following declaration in the Ofudesaki: "At this time, I, God, reveal Myself and teach the truth of all things in detail." (I: 3 ) Out of an intense love for the children, God the Parent descended from the position of absolute supremacy to, as it were, faces us humans on an equal level and intently revealed the principle of universal salvation or the truth of salvation. This Ofudesaki's verse represents the fact that God the Parent—after settling Miki as the Shrine-faught through Her, as Oyasama, sometimes by Her spoken words, sometimes by Her written words, and sometimes by Her actions as though to lead us by the hand. It is a materialization of paradoxical fact that the eternal became manifest in the temporal, and the absolute in the relative. This is the way of direct revelation. In the field of religious studies, it is called special revelation or original revelation. This revelation, which was to be revealed through other forms, began to serve as revelation through being illuminated by the light of the revelation as a special historical fact.

The other forms are taught referring to God the Parent as explained as God of Origin, God in Truth. In the Doctorine of Tenrikyo one can see the first words declared by God the Parents through Miki. That is: "I am the God of Origin, the

$\mathrm{TS}, 35$.

$\mathrm{TCH}, 20-23$

Hideo Nakajima."This universe is the body of God; Ponder this in all matters." Tenri Journal of Religion, No.32. Oyasato Institute for the Study of Religion ed. Tenri: Tenri University Press, $2004,9+17$. 
God in Truth. There is causality in this Residence. At this time I have descended here to save all humankind. I wish to receive Miki as the Shrine of God." ${ }^{10}$

Professor Nakajima stated that God the Parent came forward into this world and was revealed in order to work for world salvation. Therefore, God's intention of salvation can be considered intrinsic in all things and events in the world. Conversely put, things and events in general can be said to be revelations of God the Parent's salvation in themselves. It is taught in the Ofudesaki: "This universe is the body of God. Ponder this in all matters." (III: 40, 135) Physical troubles and events are teachings guides for salvation as shown in God's "body" as they can be said to be the guidelines for salvation revealed in their particular manner of occurrence and aspect. While special revelation or original revelation mentioned above is called direct revelation, these other forms can be called general or natural revelation as well as indirect revelation.

The above verse from the Ofudesaki is always noted in discussing the world, nature, or human beings from the standpoint of the Tenrikyo faith. It is interpreted as teaching us humans that all beings exist just as God the Parent blessings. If everything in this world is to be regarded as God the Parent's revelation, and if we are asked - as the verse requests - to ponder the veracity of the fact that everything is God's body and to understand God the Parent's intention contained therein, then we have to be prepared to responsibly comply with this request responsibly. It can be said that this is how a follower should seek the path.

Looking into the context or the sequence of meaning of the above verse through its related parts it refers to the truth of a "thing lent, a thing borrowed." For instance, verse 40 is followed by the verse that reads: "All human bodies are things lent by God. With what thought are you using them." (III: 41) And verse 135 is followed by:

At this time, as God is openly revealed,

I shall teach you any and all things. (III: 136)

So long as you remain unknowing that the body is

a thing borrowed, you can understand nothing at all. (III: 137)

At the heart of these teachings lies a deeper truth of what may appear, at first glance, to be a description of simple daily movements. All such movements are generated through a higher power than our own and one which gives life to all beings. The teachings of Miki Nakayama explain the dynamic qualities of life in

$10 \mathrm{TCH}, 3$. 
terms of the providence of God. Such providence equally permeates the world as it permeates the human body. God the Parent gives life to the world and continues to sustain it - including the human bodies which are part of the world - in the here and now.

Thus, God the Parent declares that the true way of living will be taught in its entirety. It is further explained that unless humans, who are expected to respond to God's care, know and become aware of this care, the truth of the teaching can never be seen.

In fact, humans do not easily become aware that the human body is a "thing borrowed." Once we learn this fact and think about it afresh, we cannot help marveling at the orderliness of not only human bodies but also nature's operations in general. It can be said to be a most fundamental, totally human understanding of God. This realization helps us understand that we "live by being kept alive" or are "granted life (enabled to live)" by God the Parent. This means for us to be able to understand that it is because we receive blessings from God the Parent.

Therefore, we must reflect on what initiative we should take as we live as borrowers while enjoying God the Parent's blessings. In other words, we are asked to deepen our awareness that we possess borrowed bodies. This, for instance, may indicate a way for human beings to respond to God the Parent in the process of salvation.

There is another expression in the Tenrikyo text concerning to the body of God, the Koki, or the Story of Creation, we read: "This universe is the body of both the Tsuki (Moon) and the Hi(Sun). It is in the embrace of the Heaven and the Earth. Human beings live in the bosom of Tsukihi." "' In another text, the Osashizu, Divine Directions, it is written, "Wherever you are, you will always be in the body of Tsukihi." (July 1, 1887) These are metaphoric ways of illuminating the truth of beings that "live by being kept alive" or the essence of life.

This is explained from a view of an interrelation between the world and human body by the term of 'a thing lent, a thing borrowed.' As Professor Nakajima once wrote:

If we consider the teaching "This universe is the body of God" from the opposite end of our religious awareness, that is to say, if we reflect on the aspect of our being we clearly feel the most familiar with, we will

"Shozen Nakayama. Koki no kenkyu [A study of Koki]. Tenri: Tenrikyo doyusha, 1957, 1983/10th edition), 12. 
realize that our bodies-which we take for granted as our own - are in fact not our own, cannot be controlled by us at will, and are ultimately things borrowed from God the Parent. It is a truth we learn only when we become sick or encounter some trouble. Through the things "lent" to human beings, which God calls God's own "body," God the Parent speaks to us with single-hearted parental love. ${ }^{12}$

There are many verses in the Ofudesaki which demonstrated the above.

Ponder over it! There is nothing at all which should be called illness. It is but a road sign or an admonition from God. (III: 138)

A slight ailment of the eyes, swellings, dizziness, and pain are but the guidance of God. (III: 139)

In this world, landslides, thunder, earthquakes, and great winds are all from the anger of Tsukihi. (VI: 91)

Thunder, earthquakes, great winds, and floods: these are from the regret and anger of Tsukihi. (VIII: 58)

Whatever you may dream, it is by Tsukihi. What is said, also, is all by Tsukihi. (XIV: 1)

That is why I put the fragrance even into your dreams. Quickly ponder over it, please. (XIV: 7)

Thus, illness and trouble are the "guidance" on the true path and the "care" to help us take a big step toward single-hearted salvation. And the teachings in the Osashizu such as "The human body is a thing lent, a thing borrowed" (January 8 , 1888); "The world is a mirror" (February 15, 1888); "Everything is reflected in the world. The world reflects it. The world is a mirror." (February 4, 1889) are essential for us to perceive the heavenly truth, God the Parent's blessing, or the principle of salvation that exists in all phenomena. Viewing the world taught as "God's body" this way illuminates the depth of God's blessing and of human life. The teaching about the world is understood to be a symbolic language for God the Parent's revelation.

Another form of God's revelation is mentioned by Professor Nakajima as the ten aspects of complete providences of God referred to above. He conveys the passage originally penned by Moroi as follows.

12 Hideo Nakailma, "This universe is the body of God; Ponder this in all matters," 17. 
One day when one of the followers asked Oyasama, "how far is it from east to west or from north to south?" She replied, "It is like when you lie down, stretching both of your arms." At that time Oyasama also said, "The earth is like the human body. Gold and other minerals correspond to nails in the human body. Hot springs are like the primary organs; trees and plants are like human hair; and rivers are like blood vessels. They have the same truth. ${ }^{13}$

This is an example of the understanding of the teaching "This universe is the body of God" which is the worldview presented with reference to the teaching of the "ten aspects of the complete providence." This explains God the Parent's perfect blessing that is short of nothing, is also presented by describing a kind of "correspondence" between the human body and the living environment as a whole, including the world or the natural world.

This is further illustrated in Tenrikyo that the human body is a continual manifestation of the ten aspects of the complete providence of God in corporal form - the same complete providence that appeared during the time of human creation - which realizes itself in the present. As such, then, a new creation is taking place through the same providence of God each and every minute of the day in the human body with full respect to the original creation of human beings at the very beginning of time. God initialized the creation in the human body in the present.

Then Professor Nakajima concluded in the following manner:

We would do well to ponder over the verse: "This universe is the body of God. Ponder this in all matters." The Parent's heart intent on singlehearted salvation is expressed in the verse: "Day after day, the concern of the Parent is only about the means to save you. "It is imperative that we understand the physical representation of this parental love and shed light on the world fully geared to salvation as shown in Tenrikyo's teachings in order to propose the guideposts of world salvation in the modern society. ${ }^{14}$

To sum up the above discussion, according to the "Story of the Beginning of Origin, The purpose of creating and sustaining the human body and the world is for humans to live the Joyous Life. Perceiving the human body as a "thing lent, a

13 Masakazu Moroi. Seibun-in-sho[Notes by Masakazu Moroi]. Tenri: Tenrikyo doyusha, 1970, 1980(5th edition), 158-159.

14 Hideo Nakajima, "This universe is the body of God; Ponder this in all matters," 15. 
thing borrowed," as an instrument for living the Joyous Life, we should pay particular attention as to how the human body moves about in ${ }^{15}$ fulfilling its role in expressing and drawing closer to the Joyous Life. And it is taught that God created humankind and the world in order to see human beings live the Joyous Life and share in it. The cause of all things is to live the Joyous Life and human beings have the responsibility to awaken to it, thereby carrying out this ideal, in order to carry it out into action.

The human body is a continual manifestation of the ten aspects of the complete providence of God in corporal form - the same complete providence that appeared during the time of human creation - which realizes itself in the present. As such, then, a new creation is taking place through the same providence of God each and every minute of the day in the human body with full respect to the original creation of human beings at the very beginning of time. Actually the phrase "This universe is the body of God. Ponder this in all matters," could be grasped as the cosmology for the salvation of both humanity and the universe.

\section{References:}

01. Nakayama Miki. Ofudesaki: The Tip of the Writing Brush. Tenri: Tenrikyo Church Headquaters, 1993(6th edition).

02. Nakayama Miki. Mikagura-uta: The Songs for the Service. Tenri: Tenrikyo Church Headquaters, 1999 (7th edition).

03. Tenrikyo Church Headquaters, ed., Osashizu: Divine Directions. Vols. 2-7. Tenri: 1976(pocket edition).

04. Arakawa Yoshihiro. "On 'The World is the body of God,' in the Tenri kyogaku kinkyu, no. 42. Tenri: Tenrikyo doyusha, 2006, 37-52.

05. Tenrikyo Church Headquarters. The Doctrine of Tenrikyo. Tenrikyo-doyusha, 1993(10th edition).

06. Translation Section, Tenrikyo Overseas Mission Department. Tenrikyo The Path to Joyousness. Tenri: Tenrikyo Overseas Mission Department, 1998.

07. Nakajima Hideo."This universe is the body of God; Ponder this in all matters.", Tenri Journal of Religion, No.32. Oyasato Institute for the Study of Religion ed. Tenri: Tenri University Press, 2004, 9-17.

08. Moroi Masakazu. Seibun-iin-sho [Notes by Masakazu Moroi]. Tenri: Tenrikyo doyusha, 1970, 1980 (5th edition).

09. Nakayama Shozen. Koki no kenkyu [A siudy of Koki]. Tenri: Tenrikyo doyusha, 1957, 1983(10th edition).

15 Masakazu Moroi. Seibun-iin-sho [Notes by Masakazu Moroi], 158. 